\title{
A KÁRPÁT-MEDENCE DOMBORZATÁNAK CSAPADÉKVÁLTOZÁSBAN BETÖLTÖTT SZEREPÉNEK VIZSGÁLATA REGIONÁLIS KLÍMAMODELLEK SEGÍTSÉGÉVEL
}

\author{
Torma Csaba Zsolt ${ }^{(1,2)}$ \\ ${ }^{(1)}$ Eötvös Loránd Tudományegyetem, H-1117 Budapest, Pázmány Péter sétány 1/A \\ ${ }^{(2)}$ Magyar Tudományos Akadémia \\ e-mail: tcsabi@caesar.elte.hu
}

\section{Bevezetés}

Az éghajlati modellek fontos szerepet töltenek be a jövőbeli antropogén kényszerek várható éghajlati hatásainak vizsgálatában. Napjainkban a globális klímakutatás elsődleges eszközei a globális klímamodellek (GCM), melyek leggyakrabban használt horizontális térbeli felbontása: 100-300 km. Azonban a globális klímamodellek lehetőségei a relatív durva felbontásukból adódóan regionális szinten igen korlátozottnak (szub-kontinentális szinten) tekinthető. A GCM eredményekben az éghajlati változók leírása igen sok bizonytalansággal terhelt, kiváltképp a csapadék vonatkozásában ${ }^{1}$. A numerikus előrejelző körökben jól ismert beágyazásos módszer ${ }^{2}$ során a globális modellbe illesztett (befészkelt, beágyazott) korlátos tartományú modell végzi el a globális klímamodell eredményeinek regionális szintre való leskálázását. Az első sikeres, beágyazáson alapuló regionális klímamodell (RCM) kísérletet az Amerikai Egyesült Államok nyugati partjára, $60 \mathrm{~km}$-es rácsfelbontás mellett végezték el (Dickinson et al., 1989). Az elmúlt évtizedekben esettanulmányoktól kezdve paleoklimatológiai vizsgálatokon át, a jövőre vonatkozó klimatológiai kutatásokig, valamint évszakos előrejelzésekig egyaránt alkalmaztak RCM-ket. Azonban a regionális klíma előrejelzésekben egyaránt meglévő bizonytalanságok vizsgálata ezen elörejelzések csoportos kiértékelését ${ }^{3}$ követelik meg (Beniston et al., 2007). Az elmúlt közel két évtized során Európa térségére több olyan nemzetközi program látott napvilágot, melyek során a regionális klímaváltozás vizsgálata RCM szimulációk segítségével történt: PRUDENCE (Predicting of Regional Scenarios and Uncertainties for Defining European Climate Change Risks and Effects, 2001-2004; Christensen \& Christensen, 2007); ENSEMBLES (Ensembles-Based Predicitions of Climate Changes and Their Impacts, 2004-2009; Hewit \& Griggs, 2004); CECILIA (2006-2009; Halenka, 2007). Az egyik legújabb nemzetközi kezdeményezés során (Coordinated Regional climate Downscaling Experiment, CORDEX; Giorgi et al., 2009), a Föld minden kontinensére rendelkezésre állnak RCM szimulációk (többnyire az 1950-2100 időszakra vonatkozóan). A CORDEX keretén belül az EURO-CORDEX (Jacob et al., 2014) és Med-CORDEX (Ruti et al., 2015) nemzetközi programoknak köszönhetőn példa nélküli mértékben hozzáférhetők $50 \mathrm{~km}$ és $12 \mathrm{~km}$ felbontás mellett klímaszimulációk a Kárpát-medencét teljes terjedelmében magában foglaló európai régióra. Ezen szimulációk szolgáltatják az alapját a Kárpát-medence térségére végzett kutatásaimnak.

\section{A kutatás alapgondolata}

A 2012-2016 közötti időszakban a Med-CORDEX programhoz kapcsolódóan a mediterrán térségre számos tranziens klímaszimulációt hajtottam végre $50 \mathrm{~km}$, illetve $12 \mathrm{~km}$ horizontális

\footnotetext{
${ }^{1}$ A csapadék a hőmérséklethez viszonyítva sokkal nagyobb térbeli és időbeli változékonyságot mutat.

${ }^{2}$ Nesting

${ }^{3}$ Esembles technika.
} 
rácsfelbontás mellett (Torma \& Giorgi, 2014; Giorgi et al., 2014; Coppola et al., 2014; Torma et al., 2015; Ruti et al., 2015; Liu et al., 2015; Giorgi et al., 2016; Fantini et al., 2016; Drobinski et al., 2016). Ezen tanulmányok jelentős részében az Alpok térsége megkülönböztetett figyelmet kapott. Ennek legfőbb okai: az Alpok komplex domborzata a regionális éghajlat alakításában kitüntetett szereppel bír, valamint rendelkezésre áll finom felbontású $(5 \mathrm{~km})$, kiváló minőségü, megfigyeléseken alapuló csapadék adatbázis (EURO4M-APGD, Isotta et al., 2014), mely a modellek teljesítményének részletes kiértékeléséhez kiváló alapot szolgáltat az Alpok és közvetlen környezetében. Egyik legutóbbi munkánkban (Torma et al., 2015) ezen hegyvidéki területre példák során (átlagos csapadék térbeli eloszlás, napi csapadékintenzitás eloszlás, csapadék extrémum vizsgálat) a térbeli felbontásból származó előnyöket mutattuk be. A csapadék eredményekben egyértelmü javulás mutatkozott a finom felbontású RCM-ek $(\sim 12 \mathrm{~km})$ esetében mind a közepes felbontású RCM-ek $(\sim 50 \mathrm{~km})$, mind pedig a durva felbontású GCM-ek eredményeivel összevetve. Eredményeink továbbá arra is rávilágítottak, hogy a leskálázás során az RCM-ek a GCM-ek által előrejelzett csapadékváltozást ${ }^{4}$ is nagymértékben módosították, különösképp a magasan fekvő területeken (2000 m felett). Ugyanis míg a vizsgált finom felbontású RCM-ek döntő többsége a nyári csapadékmennyiség növekedését jelezte az évszázad végére, addig a GCM-ek ennek ellenkezőjét mutatták. Következő

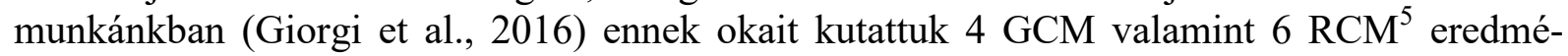
nyeinek feldolgozásával. Abban az esetben, amikor a csapadékot konvektív és nem-konvektív részenként vizsgáltuk, a $2000 \mathrm{~m}$ feletti területeken a konvektív csapadék erős, szignifikáns megnövekedését találtuk, melyre a megnövekedett potenciális instabilitás ${ }^{6}$ adott választ, ami a felszíni felmelegedés és a helyben kihullott csapadék körforgásának a következménye is egyben.

A Kárpát-medence, illetve a Kárpátok térsége klímaváltozási vizsgálatok vonatkozásában sokkal kisebb figyelmet kapott eddig klímakutatói körökben, mint az Alpok és közvetlen környezete. Az Alpok térségéhez hasonlóan a Kárpátok komplex domborzatú terület (2000 m magasságot meghaladó hegycsúcsokkal), mely befolyással van a térség éghajlatára, valamint a modellek kiértékeléséhez szintén rendelkezésre áll finom felbontású $(\sim 10 \mathrm{~km})$, jó minőségü, megfigyeléseken alapuló napi csapadékösszegeket is magában foglaló adatbázis (CARPATCLIM, Szalai et al., 2013). Ugyanakkor a térség országai számára számos mezőgazdasági, gazdasági ágazat vonatkozásában a Kárpát-medence kiemelt fontossággal bír. Példának okáért Magyarország legfőbb folyóinak egyike, a Tisza forrása ${ }^{7}$ a Kárpátokban található. Ezen tény egyben rávilágít annak fontosságára, hogy a térségünkben várható klímaváltozásról való ismereteink minél pontosabb, teljes legyen, különösképp a csapadékváltozás vonatkozásában. Mindezen tényezők igen erőteljes indítékát adják az Alpok térségére elvégzett vizsgálatok Kárpát-medencére történő adaptálására, kiterjesztésére.

\section{Várható csapadékváltozás a Kárpát-medence térségében}

A Kárpát-medence térségére jó minőségü, finom felbontású, homogenizált napi csapadékösszegek állnak rendelkezésre a CARPATCLIM adatbázis részeként (Szalai et al., 2013) az 1961-2010 közötti időszakra vonatkozóan. A CARPATCLIM adatbázis által körülhatárolt régió adja továbbá a vizsgálataim céltartományát (1. ábra).

\footnotetext{
${ }^{4}$ 2070-2099 időszak átlagát a referencia időszaknak tekintett 1976-2005 közötti átlagértékkel összevetve.

${ }_{6}^{5}$ EURO-CORDEX és Med-CORDEX szimulációk.

${ }^{6}$ Potenciális Instabilitási, vagy PI index, mely az ekvivalens potenciális hömérséklet $500 \mathrm{hPa}$ és $850 \mathrm{hPa}$ nyomási szintek közötti különbségéből származtatott: $\theta_{e 500}-\theta_{e 850}$

${ }^{7}$ Továbbá például a teljesség igénye nélkül a Maros, Szamos, Kraszna és a Körösök.
} 

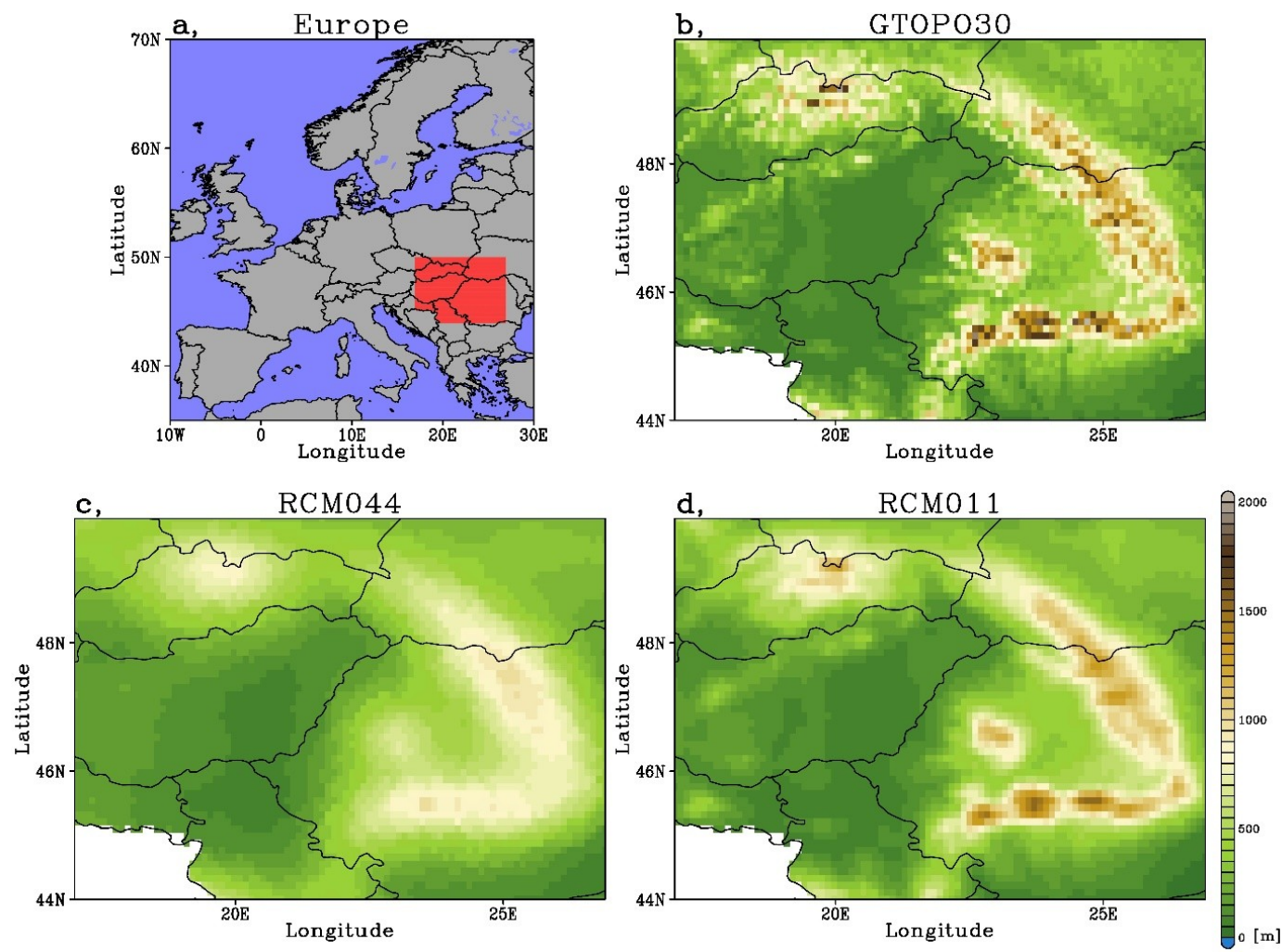

1. ábra: A vizsgálatok céltartománya, mely megegyezik a CARPATCLIM adatbázis által lefedett területtel. A kutatási terület elhelyezkedése Európán belül (a panelen piros színnel jelölve). A CARPATCLIM adatbázis által körülírt tartomány $0,11^{\circ}$ horizontális rácshálózatra interpolált domborzati térképei különböző adatbázisok alapján:

GTOPO30 (b panel; eredeti felbontás: 30"),

RCM044 (c panel; 0,44 felbontású RCM-ek átlaga),

RCM011 (d panel; 0,11º felbontású RCM-ek átlaga).

Az egyes térbeli felbontásokból adódó magasságbeli különbségek jól érzékelhetők a közepes felbontású RCM-ek ( $\sim 50 \mathrm{~km}, \mathrm{RCM} 044)$, valamint a finom felbontású RCM-ek $(\sim 10 \mathrm{~km}$, RCM011) átlagos tengerszintfeletti magasságainak összevetése során (1.ábra). Hegyvidéki környezetben az egyes modellek domborzatában több száz méteres tengerszintfeletti magasságbeli eltérések is megfigyelhetők.

A kutatás megkezdésekor az EURO- és Med-CORDEX keretében napi csapadékösszegek az RCP $8.5^{8}$ forgatókönyvet követve 8 RCM-re álltak rendelkezésre mindkét, korábban említett rácsfelbontás mellett. Az 1. táblázat foglalja össze a jelen munkához felhasznált GCM/ RCM párosokat.

Az RCM-ek által szolgáltatott csapadék adatokat három, egyenként 30 éves időszeletre vizsgáltam meg: 1976-2005 (referencia időszak), 2021-2050 (közeljövő) és 2070-2099 (távoli jövő). Az eredményeket korábbi munkánkat követve (Torma et al., 2015) a Climate Data Operators ${ }^{9}$ „distance-weighted” ${ }^{10}$ eljárását alkalmazva $0,11^{\circ}$-os rácshálózatra képeztem. Az így kapott csapadékmezőkből származtattam a várható csapadékváltozásokat leíró mezőket. Az RCM ensembles-ek térbeli felbontásuktól függetlenül a várható csapadékváltozás mértékében és térbeli eloszlásában nagymértékü hasonlóságot mutatnak (2. ábra).

\footnotetext{
${ }^{8}$ Representative Concentration Pathway 8.5, azaz olyan Koncentrációváltozás Reprezentatív Pálya, mely igen magas üvegházhatású gázkibocsátást leíró forgatókönyvet jelent.

${ }^{9} \mathrm{CDO}, \mathrm{https}$ ://code.mpimet.mpg.de/projects/cdo/

${ }^{10}$ Távolsággal arányosan súlyozott.
} 
Torma Cs.: A Kárpát-medence domborzatának csapadékváltozásban betöltött szerepének vizsgálata regionális klímamodellek segítségével

1. táblázat: A kutatáshoz felhasznált modellek.

Csillaggal jelölt modellek a Med-CORDEX keretében állnak rendelkezésre, betűvel listázottak a meghajtó mezőket szolgáltató globális klímamodellek. ${ }^{11}$

\begin{tabular}{|c|c|c|}
\hline Modell & Intézmény & Horizontális felbontás \\
\hline $\begin{array}{l}\text { a, CNRM-CM5 } \\
\text { (Voldoire et al., 2013) }\end{array}$ & $\begin{array}{l}\text { Centre National de Recherches } \\
\text { Meteorologiques and Centre } \\
\text { Europeen de Recherches et de } \\
\text { Formation Avancee en Calcul } \\
\text { Scientifique, France }\end{array}$ & $1,40625^{\circ} \times 1,40625^{\circ}$ \\
\hline $\begin{array}{l}\text { b, EC-EARTH } \\
\text { (Hazeleger et al., 2010) }\end{array}$ & $\begin{array}{l}\text { Irish Centre for High-End } \\
\text { Computing, Ireland }\end{array}$ & $1,125^{\circ} \times 1,125^{\circ}$ \\
\hline $\begin{array}{l}\text { c, HadGEM2-ES } \\
\text { (Collins et al., 2011) }\end{array}$ & Met Office Hadley Centre, UK & $1,875^{\circ} \times 1,2413^{\circ}$ \\
\hline $\begin{array}{l}\text { d, MPI-ESM-LR } \\
\text { (Jungclaus et al., 2010) }\end{array}$ & $\begin{array}{l}\text { Max Planck Institute for } \\
\text { Meteorology, Germany }\end{array}$ & $1,875^{\circ} \times 1,875^{\circ}$ \\
\hline $\begin{array}{l}\text { e, IPSL-CM5A-MR } \\
\text { (Dufresne et al., 2013) }\end{array}$ & Institut Pierre Simon Laplace & $1,25^{\circ} \times 2,5^{\circ}$ \\
\hline $\begin{array}{l}\text { ALADIN (a-MC) } \\
\text { (Colin et al., 2010) }\end{array}$ & $\begin{array}{l}\text { Centre National de Recherches } \\
\text { Meteorologiques, France }\end{array}$ & $0,11^{\circ}$ és $0,44^{\circ}$ \\
\hline $\begin{array}{l}\text { CCLM (d-EC) } \\
\text { (Rockel et al., 2008) }\end{array}$ & $\begin{array}{l}\text { Climate Limited-area Modelling } \\
\text { Community, Germany }\end{array}$ & $0,11^{\circ}$ és $0,44^{\circ}$ \\
\hline $\begin{array}{l}\text { HIRHAM (b-EC) } \\
\text { (Christensen et al. 1998) }\end{array}$ & Danish Meteorological Institute & $0,11^{\circ}$ és $0,44^{\circ}$ \\
\hline $\begin{array}{l}\text { RCA4 (c-EC) } \\
\text { (Kupiainen et al., 2011) }\end{array}$ & $\begin{array}{l}\text { Swedish Meteorological and } \\
\text { Hydrological Institute, Rossby } \\
\text { Centre, Sweden }\end{array}$ & $0,11^{\circ}$ és $0,44^{\circ}$ \\
\hline $\begin{array}{l}\text { RACMO (b-EC) } \\
\text { (Meijgaard van et al., 2012) }\end{array}$ & $\begin{array}{l}\text { Royal Netherlands Meteorological } \\
\text { Institute, The Netherlands }\end{array}$ & $0,11^{\circ}$ és $0,44^{\circ}$ \\
\hline $\begin{array}{l}\text { REMO (d-EC) } \\
\text { (Jacob et al., 2001) }\end{array}$ & $\begin{array}{l}\text { Max-Planck-Institut für } \\
\text { Meteorologie, Germany }\end{array}$ & $0,11^{\circ}$ és $0,44^{\circ}$ \\
\hline $\begin{array}{l}\text { RegCM4 (c-MC) } \\
\text { (Giorgi at al., 2012) }\end{array}$ & $\begin{array}{l}\text { International Centre for } \\
\text { Theoretical Physics, Italy }\end{array}$ & $0,11^{\circ}$ és $0,44^{\circ}$ \\
\hline $\begin{array}{l}\text { WRF331F (e-EC) } \\
\text { (Skamarock et al., 2008) }\end{array}$ & $\begin{array}{l}\text { IPSL (Institut Pierre Simon } \\
\text { Laplace) and INERIS (Institut } \\
\text { National de l'Environnement } \\
\text { industriel et des RISques) }\end{array}$ & $0,11^{\circ}$ és $0,44^{\circ}$ \\
\hline
\end{tabular}

A téli évszakra jellemző módon a modellek több csapadékot jeleznek mindkét jövőbeli időszeletre vonatkozóan (2. ábra $a-d$ ). Azonban míg a közeljövöre többnyire bizonytalan nem csak a változás mértéke, hanem annak iránya is (2. ábra $a-b)$, addig a 2070-2099 időszakra igen egyértelmü, jelentős mértékü (akár 30\%-ot meghaladó) csapadéktöbbletet jeleznek a felhasznált modellek majdnem a teljes Kárpát-medence térségére (2. ábra $c-d$ ). A nyári évszakra a téli évszakkal ellentétben, kisebb mértékü, ugyanakkor nagyobb térbeli változékonyságot mutató változásokat vetítenek elöre a modellek (2. ábra $e-h)$. Az alföldi területekre a vizsgált finom felbontású modellek kismértékü, nem szignifikáns csapadéknövekedést ( 0 -15\%-os) jeleznek (2. ábra $f-h)$. Érdemes megfigyelni azonban, hogy az évszázad végére főként a Kár-

\footnotetext{
${ }^{11}$ A regionális klímamodellek után zárójelben a GCM-nek megfelelő betű, illetve arra vonatkozó információ áll, hogy az adott RCM mely program keretében áll rendelkezésre (EC: EURO-CORDEX, MC: Med-CORDEX).
} 
pátok vonulatai és azok közvetlen környezetében lehet számítani nagyobb bizonyossággal 10-20\%-os csapadékhiányra (2. ábra $h$ ). A nyári csapadékváltozás térbeli eloszlása orografikus eredetre utal, melynek részletesebb vizsgálata további munkát igényel.

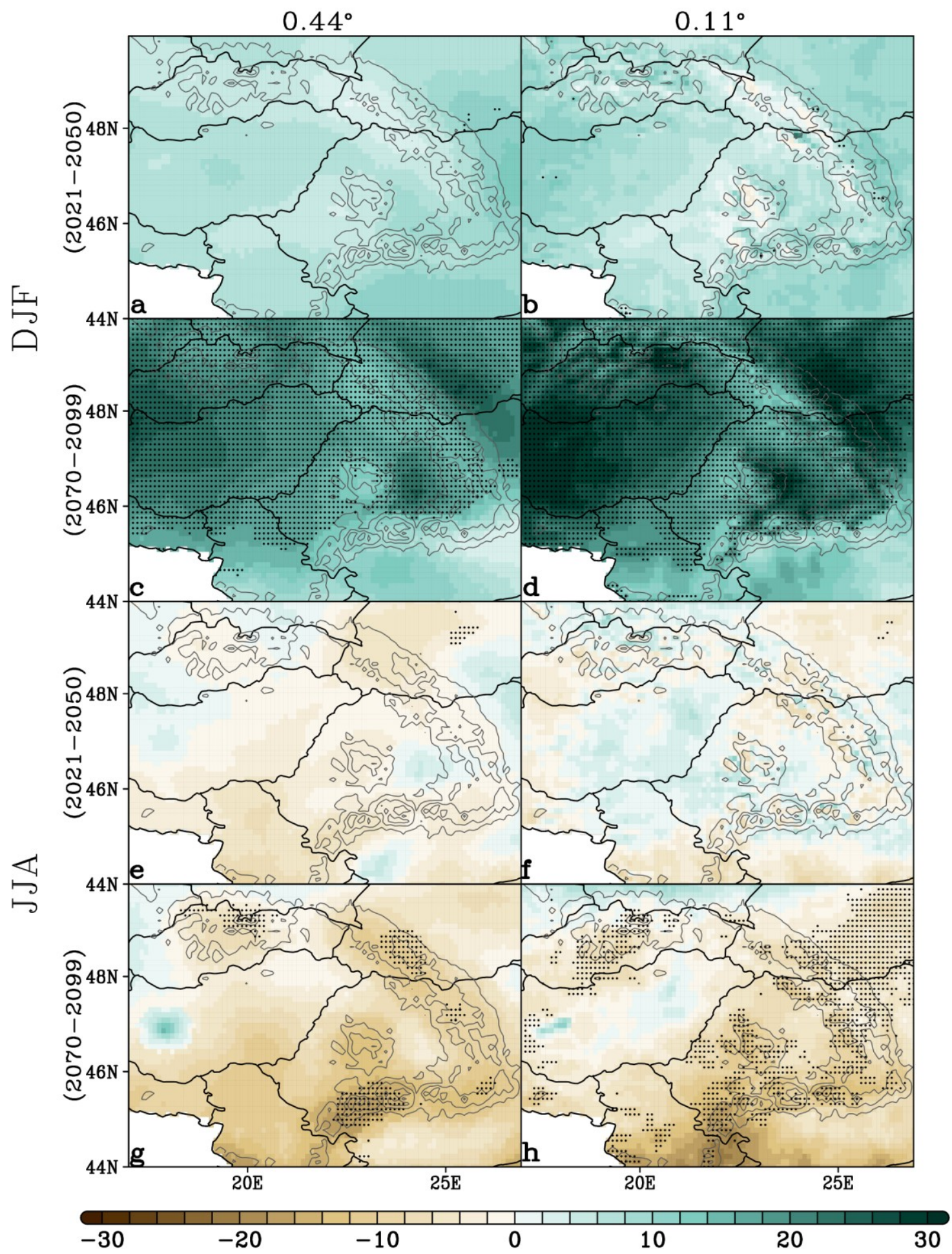

2. ábra: Várható csapadékváltozás a 2021-2050 és 2070-2099 időszakokra (referencia időszak: 1976-2005) nyár (JJA) és tél (DJF) évszakokra. Pontokkal kiemelt területek azon

régiókat jelölik, ahol a modellek többsége ( 8 modell közül legalább 5) szignifikáns (kétmintás t-próba, $\mathrm{p}=0,1$ ) változást jeleznek. Az eredmények \%-ban vannak feltüntetve. 


\section{Köszönetnyilvánítás}

A kutatásokat az MTA Prémium Posztdoktori ösztöndíj támogatja. Köszönet illeti továbbá az EURO-CORDEX és Med-CORDEX modellező csoportokat, a CARPATCLIM, Database () European Commission - JRC 2013 csapatát, valamint a U.S. Geological Survey-t, hogy a GTOPO30 adatbázisaikat közzétették. Jelen munkában felhasznált adatok többek között a következő honlapokon keresztül érhetők el, tölthetök le: http://cordexesg.dmi.dk/esgf-web-fe/ (EURO-CORDEX), http://www.medcordex.eu/medcordex.php (MED-CORDEX), http:// www.carpatclim-eu.org/pages/download/ (CARPATCLIM).

\section{Hivatkozások}

Beniston, M., Stephenson, D.B., Christensen, O.B., Ferro, C.A.T., Fre, C., Goyette, S., Halsnaes, K., Holt, T., Jylhä, K., Koffi, B., Palutikof , J., Schöl, R., Semmler, T., Woth, K., 2007: Future extreme events in European climate: An exploration of regional climate model projections. Clim. Change, 81 (Supplement 1): 71-95. https://doi.org/10.1007/s10584-006-9226-z

Christensen, O.B., Christensen, J. Machenhauer, H.B., Botzet, M., 1998: Very high-resolution regional climate simulations over Scandinavia-Present climate. J. Climate, 11: 32043229. https://doi.org/10.1175/1520-0442(1998)011<3204:VHRRCS $>2.0 . C O ; 2$

Christensen, J.H., Christensen, O.B., 2007: A summary of the PRUDENCE model projections of changes in European climate by the end of this century. Clim. Change, 81 (Supplement 1): 7-30. https://doi.org/10.1007/s10584-006-9210-7

Colin, J., Deque, M., Radu, R., Somot, S., 2010: Sensitivity studies of heavy precipitations in limited area model climate simulation: influence of the size of the domain and the use of the spectral nudging technique. Tellus A, 62: 591-604. https://doi.org/10.1111/j.16000870.2010.00467.x

Collins, W.J., Bellouin, N., Doutriaux-Boucher, M., Gedney, N., Halloran, P., Hinton, T., Hughes, J., Jones, C. D., Joshi, M., Liddicoat, S., Martin, G., O'Connor, F., Rae, J., Senior, C., Sitch, S., Totterdell, I., Wiltshire, A., and Woodward, S., 2011: Development and evaluation of an Earth System model - HADGEM2. Geosci. Model Dev., 4: 1051-1075. https://doi.org/10.5194/gmd-4-1051-2011

Coppola, E., Giorgi, F., Raffaele, F., Fuentes-Franco, F., Giuliani, G., Llopart-Pereira, M., Mamgain, A., Mariotti, L., Diro, T. G., Torma, Cs.Zs., 2014: Present and future climatologies in the phase I CREMA experiment. Clim. Change, 125: 23-38. https://doi.org/10.1007/s10584-014-1137-9

Dickinson, R.E., Errico, R.M., Giorgi, F., Bates, G.T., 1989: A regional climate model for the western United States. Clim. Change, 15: 383-422. https://doi.org/10.1007/BF00240465

Drobinski, P., Da Silva, N., Panthou, G., Bastin, S., Muller, C., Ahrens, B., Borga, M., Conte, D., Fosser, G., Giorgi, F., Güttler, I., Kotroni, V., Li, L., Morin, E., Önol, B., QuintanaSegui, P., Romera, R., Torma, Cs.Zs., 2016: Scaling precipitation extremes with temperature in the Mediterranean: past climate assessment and projection in anthropogenic scenarios. Clim. Dyn., 51(3): 1237-1257. https://doi.org/10.1007/s00382-016-3083-x

Dufresne, J.L., Foujols, M.A., Denvil, S. et al., 2013: Climate change projections using the IPSL-CM5 Earth System Model: from CMIP3 to CMIP5. Clim. Dyn., 40(9-10): 2123-2165. https://doi.org/10.1007/s00382-012-1636-1

Fantini, A., Raffaele, F., Torma, Cs., Bacer, S., Coppola, E., Giorgi, F., 2016: Assessment of multiple daily precipitation statistics in ERA-Interim driven Med-CORDEX and EURO- 
TCORDEX experiments against high resolution observations. Clim. Dyn., 51(3): 877-900. https://doi.org/10.1007/s00382-016-3453-4

Giorgi, F., Jones, C., Asrar, G., 2009: Addressing climate information needs at the regional level: The CORDEX framework. WMO Bulletin, 58: 175-183.

Giorgi, F., Coppola, E., Raffaele, F., Diro, G. T., Fuentes-Franco, R., Giuliani, G., Mamgain, A., Llopart Pereira, M., Mariotti, L., Torma, Cs., 2014: Changes in extremes and hydroclimatic regimes in the CREMA ensemble projections. Clim. Change, 125(1): 39-51. https://doi.org/10.1007/s10584-014-1117-0

Giorgi, F., Coppola, E., Solmon, E., Mariotti, L., Sylla, M.B., Bi, X., Elguindi, N., Diro, G.T., Nair, V., Giuliani, G., Turuncoglu, U.U., Cozzini, S., Güttler, I., O’Brien, T.A., Tawfik, A.B., Shalaby, A., Zakey, A.S., Steiner, A.L., Stordal, F., Sloan, L.C., Brankovic, C., 2012: RegCM4: model description and preliminary results over multiple CORDEX domains. Clim. Res., 52: 7-29. https://doi.org/10.3354/cr01018

Giorgi, F., Torma, Cs., Coppola, E., Ban, N., Schär, C., Somot, S., 2016: Enhanced summer convective rainfall at Alpine high elevations in response to climate warming. Nat. Geosci., 9: 584-589. https://doi.org/10.1038/ngeo2761

Halenka, T., 2007: On the Assessment of Climate Change Impacts in Central and Eastern Europe - EC FP6 Project CECILIA. Geophysical Research Abstracts, 9: 10545.

Hazeleger, W., Severijns, C., Semmler, T., Stefanescu, S., Yang, S., Wang, X., Wyser, K., Dutra, E., Baldasano, J.M., Bintanja, R., Bougeault, P., Caballero, R., Ekman, A.M.L., Christensen, J.H., van den Hurk, B., Jimenez, P., Jones, C., Kallberg, P., Koenigk, T., McGrath, R., Miranda, P., vín Noije, T., Palmer, T., Parodi, J.A., Schmith, T., Selten, F., Storelvmo, T., Sterl, A., Tapamo, H., Vancoppenolle, M., Viterbo, P., Willén, U., 2010: ECEARTH: a seamless Earth system prediction approach in action. Bull. Am. Meteorol. Soc., 91: 1357-1375. https://doi.org/10.1175/2010BAMS2877.1

Hewitt, C.D., Griggs, D., 2004: Ensembles-Based Predictions of Climate Changes and Their Impacts. Eos Trans. AGU, 85(52), 566p. https://doi.org/10.1029/2004EO520005

Isotta, F.A., Frei, C., Weilguni, V., Tadic, M.P., Lasségues, P., Rudolf, B., Pavan, V., Cacciamani, C., Antolini, G., Ratto, S.M., Munari, M., Micheletti, S., Bonati, V., Lussana, C., Ronchi, C., Panettieri, E., Marigo, G., Vertacnik, G., 2014: The climate of daily precipitation in the Alps: Development and analysis of a high resolution gridded dataset from pan-Alpine raingauge data. Int. J. Climatol., 34: 1657-1675. https://doi.org/10.1002/joc.3794

Jacob, D., Van den Hurk, B.J.J.M., Andrae, U., Elgered, G., Fortelius, C., Graham, L.P., Jackson, S.D., Karstens, U., Köpken, C., Lindau, R., Podzun, R., Rockel, B., Rubel, F., Sass, B.H., Smith, R.N.B., Yang, X., 2001: A comprehensive model intercomparison study investigating the water budget during the BALTEX-PIDCAP period. Meteorol. Atmos. Phys., 77: 19-43. https://doi.org/10.1007/s007030170015

Jacob, D., et al. (38 authors) EURO-CORDEX, 2014: New high resolution climate change projections for European impact research. Reg. Environ. Chang., 14: 563-578. https://doi.org/10.1007/s10113-013-0499-2

Jungclaus, J.H., Lorenz, S.J., Timmreck, C., Reick, C.H., Brovkin, V., Six, K., Segschneider, J., Giorgetta, M.A., Crowley, T.J., Pongratz, J., Krivova, N.A., Vieira, L.E., Solanki, S.K., Klocke, D., Botzet, M., Esch, M., Gayler, V., Haak, H., Raddatz, T.J., Roeckner, E., Schnur, R., Widmann, H., Cluassen, M., Stevens, B., Marotzke, J., 2010: Climate and carbon cycle variability over the last millennium. Clim. Past, 6: 723-737. https://doi.org/10.5194/cp-6-723-2010

Kupiainen, M., Jansson, C., Samuelsson, P., Jones, C., Willén, U., Wang, S., Döscher, R., 2014: Rossby Centre regional atmospheric model, RCA4. Rossby Centre Newslett., 
http://www.smhi.se/en/research/research-Departments/climate-research-rossby-centre2$552 / 1.16562$

Liu, L., Solmon, F., Vautard, R., Hamaoui-Laguel, L., Torma, Cs.Zs., Giorgi, F., 2015: Estimates of common ragweed pollen emission and dispersion over Europe using RegCMpollen model. Biogeosciences Discuss., 12: 17595-17641. https://doi.org/10.5194/bgd-1217595-2015

van Meijgaard, E., van Ulft, L.H., Lenderink, G., de Roode, S.R., Wipfler, L., Boers, R., Timmermans, R.M.A., 2012: Refinement and application of a regional atmospheric model for climate scenario calculations of Western Europe. KvR 054/12, 46p.

Rockel, B.,Will, A., Hense, A., 2008: The Regional Climate Model COSMO-CLM (CCLM). Meteorol. Z., 17(4): 347-348. https://doi.org/10.1127/0941-2948/2008/0309

Ruti, S.M., Somot, S., Giorgi, F., Dubois, C., Flaounas, E., Obermann, A., Dell'Aquila, A., Pisacane, G., Harzallah, A., Lombardi, E., Ahrens, B., Akhtar, N., Alias, A., Arsouze, T., Aznar, R., Bastin, S., Bartholy, J., Béranger, K., Beuvier, J., Bouffies-Cloché, S., Brauch, J., Cabos, W., Calmanti, S., Calvet, J-C., Carillo, A., Conte, D., Coppola, E., Djurdjevic, V., Drobinski, P., Elizalde-Arellano, A., Gaertner, M., Galàn, P., Gallardo, C., Gualdi, S., Goncalves, M., Jorba, O., Jordà, G., L'Heveder, B., Lebeaupin-Brossier, C., Li, L., Liguori, G., Lionello, P., Maciàs, D., Nabat, P., Önol, B., Raikovic, B., Ramage, K., Sevault, F., Sannino, G., Struglia, MV., Sanna, A., Torma, Cs., Vervatis, V., 2015: MEDCORDEX initiative for Mediterranean Climate studies. Bull. Amer. Meteor. Soc., 97(7): 1187-1208. https://doi.org/10.1175/BAMS-D-14-00176.1

Skamarock, W.C., Klemp, J.B., Dudhia, J., Gil, D.O., Duda, D.M.B.M.G., Huang, X-Y., Wang, W., Powers, J.G., 2008: A description of the advanced research WRF version 3. NCAR Technical note 475. 125p. https://doi.org/10.5065/D68S4MVH

Szalai, S., Auer, I., Hiebl, J., Milkovich, J., Radim, T., Stepanek, P., Zahradnicek, P., Bihari, Z., Lakatos, M., Szentimrey, T., Limanowka, D., Kilar, P., Cheval, S., Deak, Gy., Mihic, D., Antolovic, I., Mihajlovic, V., Nejedlik, P., Stastny, P., 738 Mikulova, K., Nabyvanets, I., Skyryk, O., Krakovskaya, S.,Vogt, J., Antofie, T., Spinoni, J., 2013: Climate of the Greater Carpathian Region. Final 740 Technical Report. http://www.carpatclim-eu.org.

Torma, Cs., Giorgi, F., 2014: Assessing the contribution of different factors in regional climate model projections using the factor separation method. Atmos. Sci. Let., 15: 239-244. https://doi.org/10.1002/as12.491

Torma, Cs., Giorgi, F., Coppola, E., 2015: Added value of regional climate modeling over areas characterized by complex terrain-Precipitation over the Alps. J. Geophys. Res. Atmos., 120: 3957-3972. https://doi.org/10.1002/2014JD022781

Voldoire, A., Sanchez-Gomez, E., Salas y Mélia, D., Decharme, B., Cassou, C., Sénési, S., Valcke, S., Beau, I., Alias, A., Chevallier, M., Déqué, M., Deshayes, J., Douville, H., Fernandez, E., Madec, G., Maisonnave, E., Moine, M-P., Planton, S., Saint-Martin, D., Szopa, S., Tyteca, S., Alkama, R., Belamari, S., Braun, A., Coquart, L., Chauvin, F., 2013: The CNRM-CM5 global climate model: description and basic evaluation. Clim. Dyn., 40: 2091-2121. https://doi.org/10.1007/s00382-011-1259-y

\section{ORCID}

Torma Cs. Zs. (D) https://orcid.org/0000-0002-4240-0788 